\section{POST-GRADUATE TEACHING IN LONDON :} COMMENTS OF AN OVERSEAS DOCTOR.

As a New Zealand doctor of some years' experience, and as one who has visited several countries in search of post-graduate work, I have been asked to comment on the post-graduate medical instruction at present available in London. In the following remarks $I$ have endeavoured to set out the adverse criticisms I have to make on the present arrangements-speaking, of course, from my own experience, which, however, I find is confirmed by other post-graduates. I have also been asked to formulate a scheme of post-graduate instruction which-though I realise it to be Utopian in design-may perhaps set out more clearly the needs of the average post-graduate.

I think as an example of what I mean a few remarks on the dental profession will not be irrelevant.

$r$ have heard it said that the dentists trained in U.S.A. are doing the best work because the training there is so thorough, and because the work is along the lines of one or more definite schools. They are taught to work long hours, and to talk of little else but their work, and they meet after working hours in societies to discuss dentistry. On returning to New Zealand they carry out the same system. I know this to be true, having had the privilege of being a guest at some of their meetings. Dentists, even after a long day's work, will meet in a member's office, and actually do work on patients and models. Papers are not read, but cases are discussed informally, and each man's work is freely criticised. The result is what one would expect.

It has been said that dentists trained in Great Britain use dentistry purely as a means of living, and expect to get the maximum of fun out of life, at golf, cards, racing, dancing, \&c. Tools are downed on the slightest excuse, and their work suffers. At the present time, football matches, shows of all sorts, odd race meetings, golf, and many other distractions are interfering with routine and steady work.

Turning now to post-graduate medical work as I know it, and as I have seen it on three different occasions, my comments are as follows.

Here in London the medical schools and hospitals are widely separated, and much time is wasted in getting from one to another. At the house of the Royal Society of Medicine there is a list posted daily giving the operations for the day, but in order to take full advantage of these lists one must live near Wimpole-street, as many of the operations are scheduled for 9 o'clock. The Fellowship of Medicine issues a monthly "Bulletin" giving particulars of work each day at the various hospitals in association with it. I have been to several hospitals, and the following occurrences $\frac{\text { on }}{0}$ move me to complain :-

1. An operator arrived long after the scheduled time. 2. An instructor was late in arriving, and in consequence was too hurried to do the work $\varrho$ thoroughly. 3. A notice was posted to say that ${ }^{C}$ Mr. So-and-So regretted his inability to take the clinic that day.

I may remark that the above complaints refer등 to different hospitals in each case.

At the present moment there are only two $\overparen{\odot}$ courses open to a post-graduate-either he can attend the larger hospitals (with medical schools) कs where the best men of the profession are to be $\vec{O}$ found, but where the teaching given is, of course, elementary ; or he must go to the smaller hospitals where the members of the staff have hardly the experience of the senior men.

The present special hospitals are necessary for giving a preliminary training to recently graduatedir men, but they do not cater for the more advanced 8 post-graduates.

As to teaching ability-i.e., the persuasive power $\stackrel{\circ}{\stackrel{5}{\lrcorner}}$ of imparting knowledge-where is it to be found ? Men do not hold hospital appointments because of $\mathcal{O}^{\mathbb{Q}}$ their ability to impart knowledge.

\section{Special Post-Graduate Hospital.}

Having made my comments on the post-graduate $\vec{\oplus}$ instruction at present available in London, I should ${ }^{\circ}$ now like to turn to the constructive side of criticism, and to outline what appear to me to be the points most to be emphasised in post-graduate medicalo work.

A special hospital should be established, and its $\stackrel{\mathbb{Q}}{\stackrel{\Phi}{\complement}}$ senior staff should be selected from among successful $\overrightarrow{\vec{A}}$ London or provincial medical men-that is to say, men who are successful in getting good results on? their patients, and also successful in teaching.

It has been suggested to me that one of the London hospitals should be made into a post- 3 graduate hospital. The difficulty in such a caseo would be the honorary staff, which would either? have to seek appointments at other hospitals oro would have to remain on as the post-graduate staff-which severely limits choice.

The teachers should be on a full-time basis and should be paid a good salary out of the feeso received from post-graduates, and instruction to senior men should not be mixed with that given to juniors. The teacher would have more joy in 0 discussing work with a man who knows a fair w amount of the subject in question than in tryingo to explain what the "Cone Light" is to a perfectly ignorant man. These teachers must be selected without fear or favour-though I realise that this? will be a great difficulty. The selectees should allo be over 45 years of age, for these reasons :-

1. Because their experience will give themp opinions of their own.

2. Because their age should make them unbiased in discussing the opinions and work of other successful practitioners. 
3. Because men of about 50 or more, who have completed their terms in hospitals and would be available, are at present without the opportunity of imparting their knowledge to post-graduates.

It should be remembered that post-graduates are not boys of 30 or less. They are men in busy practice who wish to freshen their minds and learn new methods.

Now comes the question of what fees the postgraduate would be inclined to pay. Speaking as one who comes from abroad, I personally would be willing to pay an inclusive fee of 50 guineas for a month's tuition, or 100 guineas for a ten weeks' course-a week to consist of five and a half days, containing six or more hours per day.

For such fees I should expect-

1. To see selected out-patients and hear their cases discussed by a master in his own subject. This master should outline his own course of teaching and then be able to give the various forms of diagnosis and treatment by first-rank men in Europe and America. I am not in favour of too many out-patient cases being shown, as the work suffers from the lack of reasonable time to deal with numbers. It is better to limit the outpatient cases by more systematic and thorough work.

2. To visit wards daily and to follow up medical cases and to see surgical dressings.

3. To find that all possible examinations (pathological and bacteriological) in regard to a case were done and could be seen-e.g., if a piece of tissue were removed from a body the tissue should be examined in every case and records kept which would be available to post-graduates while the patient is in hospital.

4. To see operations done in all branches of any specialty.

5. To visit other operators in the city on certain days. A number of specialists should be extra. murally associated with the hospital and they should set aside one afternoon a week for postgraduates.

6. To possess a first-class $X$ ray department and operator, such as Dr. Manger, who assists Chevalier Jackson in America.

7. To see demonstrations on the cadaver and models.

8. To have constant revision of anatomy and opportunity for private or team study by the post-graduates themselves.

I should not expect, or desire-

1. Lectures of any systematic sort, or a collection of cases and an address thereon.

2. Long-winded dissertations on this or that theory, or an autobiography of the teacher.

The aim of such a post-graduate hospital should be to improve the knowledge of all the practitioners and specialists throughout the Empire. It might even be possible in time to give senior and junior post-graduate courses. Some of us would like to have our elementary knowledge refreshed, while others would wish to see the latest improvements in the art and science of the profession. This should appeal to the teachers in Great Britain as a change from the perpetual teaching of elementary subjects to students, and they would probably appreciate the greater opportunities afforded in teaching advanced work to those who understand.

Among the students I class the young graduates who wish at once to specialise. They should not be mixed up with the men who have been specialising for years, particularly as there are ample opportunities for them to learn in such posts as that of house surgeon or clinical assistant.

The London doctor perhaps does not realise the value of time, nor the eager desire for improvement of knowledge and technique on the part of Dominion post-graduates! Six months, or even five, away from a practice, besides the expense, means a great loss, and the building up again of what has been dropped in one's absence. It cannot be impressed too strongly on people over here that it is work, and still more work, and not amusement that the visiting man is hungering for.

It must be admitted that post-graduate tuition is in a far more advanced state abroad than in Great Britain and this seems a pity, as the moral standard of this country is on a plane by itself. I for one am anxious to see the young man from overseas come to the mother country to study, and feel sure that this object will be attained if the necessary improvements can be made in the present. day instruction.

\section{Letters to the Editor}

\section{POST-GRADUATE INSTRUCTION : AN APPRECIATION.}

SIR,-I am writing in appreciation of post-graduate work as undertaken in London. During the past 20 years I have visited London many times for the purpose of postgraduate work. I have always derived great benefit, but up to 1919 there was a considerable waste of time in search of one's requirements. In 1919 the Fellowship of Medicine was started and one at once appreciated the great help such an organisation was to be to post-graduates. The wealth of material in London in the various departments of the general or special hospitals is extraordinary. The senior and junior staffs are always most helpful ; one is welcomed and afforded every opportunity of gaining an all-round general brush-up or in one or other of the special departments, if he so desires. It is impossible to prevent a repetition of what is already known to one, but, truly, this recapitulation is beneficial and is always intermixed with some more modern method, or one more useful, or the recapitulation has served to explain an imperfect previous knowledge. To undertake a syllabus of a P.G. course in its entirety is a real "burnisher" to a post-graduate. Certain lectures given at 11, Chandos-street and the Royal College of Surgeons are useful and much appreciated adjuncts to a P.G. course in London.

Many like myself leave London after a stay of four months feeling that they have been fully rewarded by taking a course of post-graduate work in London.

I have the honour to be, Sir, yours faithfully, Cecir E. Jones-Phinuripson, Late President, B.M.A., Cape of Good Hope Branch. Adderley-street, Capetown, South Africa, Jan. 4th, 1926. 